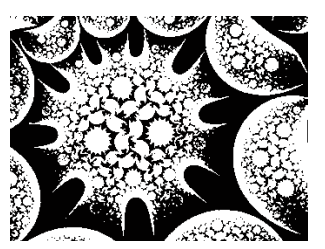

doi: $10.5559 /$ di.24.1.04

\title{
THE ROLE OF PERFECTIONISM AND EMOTIONAL REGULATION IN EXPLAINING DECISION- -MAKING STYLES
}

Andreja BUBIĆ

Faculty of Humanities and Social Sciences, Split

UDK: 159.947:159.942

Izvorni znanstveni rad

Primlieno: 14. 9. 2014.

Individuals differ in the manner they approach decision making, namely their decision-making styles. While some people typically make all decisions fast and without hesitation, others invest more effort into deciding even about small things and evaluate their decisions with much more scrutiny. The goal of the present study was to explore the relationship between decision-making styles, perfectionism and emotional processing in more detail. Specifically, 300 college students majoring in social studies and humanities completed instruments designed for assessing maximizing, decision commitment, perfectionism, as well as emotional regulation and control. The obtained results indicate that maximizing is primarily related to one dimension of perfectionism, namely the concern over mistakes and doubts, as well as emotional regulation and control. Furthermore, together with the concern over mistakes and doubts, maximizing was revealed as a significant predictor of individuals' decision commitment. The obtained findings extend previous reports regarding the association between maximizing and perfectionism and provide relevant insights into their relationship with emotional regulation and control. They also suggest a need to further explore these constructs that are, despite their complex interdependence, typically investigated in separate contexts and domains.

Keywords: decision commitment, decision making, emotional regulation and control, maximizing, perfectionism

$\triangle \quad$ Andreja Bubić, University of Split, Faculty of Humanities and Social Sciences, Chair for Psychology, Put iza nove bolnice 10c (Klerikat), 21000 Split, Croatia. 
Every day, we all make countless decisions, only some of which are recognized as expressions of our own needs and desires. For example, we are all aware of the fact that we decide what careers to pursue, schools and colleges to attend, partners and friends to spend our time with, as well as the new cars, couches or toasters to purchase. However, in addition to these decisions, we make numerous small choices daily regarding, e.g., what to eat for dinner, what movie to see in the cinema, what to buy in the supermarket, whom to ask for help. Although some of the latter types of decisions we sometimes make almost automatically because we have formed strong habits that facilitate them, many of these behaviors are nevertheless associated with conscious thoughts and judgments, as well as explicit intentions and decisions (Ariely \& Norton, 2011; Schneider \& Shiffrin, 1977; Shiffrin \& Schneider, 1977, 1984). While this is characteristic of all people, we all differ in the way we approach our decisions in various situations (Appelt, Milch, Handgraaf, \& Weber, 2011). Some people make both "small" and "big" decisions easily and can, almost effortlessly and without hesitation, choose both what to wear in the morning and which house to buy. In contrast, others may always experience difficulties while deciding, as they constantly scrutinize over each imaginable alternative in fear that their final choice will not be satisfying or that an unchosen alternative will later prove superior to the chosen one (Schwartz et al., 2002). They always want to make the best possible decision: choose the clothes appropriate for all situations they might encounter during the day; choose a mobile phone that is, at the same time, cheap, practical, efficient and stylish; choose a job that will make them happy, socially content, financially secure and self-fulfilled.

The importance of understanding individuals' tendency towards making perfect choices in various life contexts has long been recognized in the field of personality and clinical psychology (Burns, 1980; Ellis, 1962; Enns \& Cox, 2002; Greblo, 2012; Lo \& Abbott, 2013), while in recent years these issues have also gained more attention within cognitive psychology (Schwartz et al., 2002). Specifically, the interest in the dedication to high standards and the eternal quest for perfection has been recognized as a crucial component of perfectionism that Freud considered to be a feature of abnormal behavior (Hill, McIntire, \& Bacharach, 1997). The interest in perfectionism continued within the field of clinical psychology and extended to the study of its relationship with more adaptive forms of behavior (Enns \& Cox, 2002; Greblo, 2012; Lo \& Abbott, 2013). Despite this, dysfunctional attitudes and irrational 
DRUŠ. ISTRAŽ. ZAGREB GOD. 24 (2015), BR. 1 STR. $69-87$

BUBIĆ, A.: THE ROLE OF... beliefs coupled with strivings towards unachievable goals have traditionally been considered as prime features of perfectionism (Burns, 1980; Ellis, 1962), while newer research suggests that this association may be restricted to maladaptive forms of perfectionism (Stöber \& Otto, 2006). In addition, perfectionism is also characterized by absolute thinking, such that perfectionists display extreme self-criticism and are overly focused on their mistakes and potential failures (Hewitt \& Flett, 1991). Although perfectionism was earlier considered a unidimensional construct (Burns, 1980; Garner, Olmstead, \& Polivy, 1983; Weissman \& Beck, 1978), later studies have led to its substantial redefinition (Frost, Marten, Lahart, \& Rosenblate, 1990; Hewitt \& Flett, 1991), albeit not without criticisms (Shafran, Cooper, \& Fairburn, 2002). Consequently, today perfectionism is considered a multidimensional trait with negative and maladaptive, as well as positive and adaptive features and functions (Hamachek, 1978; Slade \& Owens, 1998; Stöber \& Otto, 2006).

In addition to being explored with regard to personality traits and different clinical symptoms, in recent years the tendency of setting high standards has been more and more investigated within the field of judgment and decision making. Specifically, although classical decision making models have posited that all people make rational and informed decisions (Von Neumann \& Morgenstern, 1944), it has been shown that people systematically violate the assumptions of such an ideal rational model (Kahneman \& Tversky, 1979, 1984; Simon, 1955). Also, it has been recognized that, in addition to the objective lack of all relevant information, a big problem in decision making includes the inability to deal with too much available information that is associated with a number of negative wellbeing risks (Schwartz, 2000). In that context, two opposite tendencies or decision making styles (Appelt et al., 2011), namely maximizing and satisficing, have been suggested to reflect the way people approach decision making and deal with information available during that process (Schwartz et al., 2002). While maximizers always aim towards the best possible outcome that they try to achieve by collecting and reflecting on all relevant information, satisficers have a tendency to settle with an outcome that is good enough to satisfy a less ambitious criterion. These tendencies have some long-term consequences, such that maximizing is associated with higher regret following decision making, as well as lower happiness and life satisfaction (Schwartz et al., 2002). This may be explained if we consider the fact that, although we all want the best for us, in reality it is hard to make a perfect choice in almost any, let alone every situation. In addition, in daily life it is hard to evaluate many decisions as clearly good or bad, 
DRUŠ. ISTRAŽ. ZAGREB GOD. 24 (2015), BR. 1, STR. 69-87

BUBIĆ, A.: THE ROLE OF.. as this requires comparing them to the unknown outcomes of unrealized alternatives. Nevertheless, people with very high standards frequently face situations in which the outcomes of their decisions fail their overly optimistic expectations, which may explain why they often experience regret (Roets, Schwartz, \& Guan, 2012).

The described characteristics of maximizing are somewhat similar to several aspects of perfectionism, in particular with regard to setting high personal standards and being sensitive to errors (Frost et al., 1990). In accordance with this, previous studies investigating this issue revealed moderate positive correlations between maximizing and self-oriented perfectionism (Schwartz et al., 2002), as well as positive and negative perfectionism (Bergman, Nyland, \& Burns, 2007). However, in these studies more fine-grained dimensions of perfectionism were not explored. Thus, the present study probed the relationship between maximizing and perfectionism in more detail by using the Frost Multidimensional Perfectionism Scale (FMPS; Frost et al., 1990), a multifaceted perfectionism scale designed to measure six or, as recently argued (Stöber, 1998), four distinct dimensions of this construct. These include concern over mistakes and doubts, parental expectations and criticism, personal standards and organization. Furthermore, the relationship between maximizing, perfectionism and emotional regulation and control was also investigated. This was motivated by previous reports that indicate an association between some aspects of emotional processing with both maximizing and perfectionism. For instance, maximizing has been associated with individuals' tendency to experience certain types of, typically negative, emotions such as regret (Roets et al., 2012; Schwartz et al., 2002), while previous studies have also demonstrated an association between perfectionism and emotional dysregulation (Aldea \& Rice, 2006; Rudolph, Flett, \& Hewitt, 2007). In addition to maximizing, the present study also explored the contribution of perfectionism and emotional regulation and control to one additional feature of decision making that is related to the way we evaluate the outcomes of our decision-making process. Specifically, while making decisions we all reach a stage in which we can evaluate the made choice, accept it as our decision and commit to it, or continue to keep other alternatives open, often experiencing regret because these were not chosen. While previous findings have indicated the relationship between maximizing, some aspects of perfectionism and one's tendency to experience regret (Bergman et al., 2007; Schwartz et al., 2002), their association with the propensity to commit to own choices has not been explored in such detail (Sparks, Ehrlinger, \& Eibach, 2012). In addition, the relation- 
DRUŠ. ISTRAŽ. ZAGREB GOD. 24 (2015), BR. 1 STR. 69-87

BUBIĆ, A.: THE ROLE OF... ship between maximizing, decision commitment and emotional regulation and control has thus far not been clarified. Therefore, these questions were addressed in the present study where it was hypothesized that emotional regulation and control as well as some dimensions of perfectionism would be associated with maximizing and individuals' readiness to commit to made decisions. Specifically, it was expected that higher concern over mistakes and doubts together with higher personal standards would be associated with a higher level of maximizing and decision commitment. In addition, it was hypothesized that higher levels of emotional regulation and control would be associated with higher maximizing, but not decision commitment scores. Finally, maximizing was expected to serve as an additional predictor of decision commitment, as this variable reflects the manner of evaluating choices in the post-decision stage while maximizing itself is more focused on the period during which the decisions are made (Sparks et al., 2012).

\section{METHOD}

\section{Participants}

\section{Procedure}

\section{Instruments}

Among 300 college students (average age $M=20.99$ years, $S D=2.45)$ who participated in the present study, $12(4 \%)$ were male and $283(94.3 \%)$ female, while $5(1.7 \%)$ had not reported their gender. The participants were students at the University of Split, majoring in different social studies (sociology, pedagogy) and humanities (e.g., history, philosophy, art history).

Participants were approached at the University where they completed the following instruments: Short Maximizing Scale (Nenkov, Morrin, Schwartz, Ward, \& Hulland, 2008), Decision Commitment Scale (Sparks et al., 2012), Frost Multidimensional Perfectionism Scale (FMPS; Frost et al., 1990; Zubčić \& Vulić-Prtorić, 2008) and Emotional Regulation and Control Scale (Upitnik emocionalne regulacije i kontrole, UERK; Takšić, 2002).

\section{Frost Multidimensional Perfectionism Scale}

Frost Multidimensional Perfectionism Scale (FMPS; Frost et al., 1990; Zubčić \& Vulić-Prtorić, 2008) is a scale that consists of 35 items (e.g., I usually have doubts about the simple everyday things I do) that the participants rate on a 5-point Likert-type scale ( 1 - strongly disagree; 5 - strongly agree). Although originally designed to measure six dimensions of perfection- 
DRUŠ. ISTRAŽ. ZAGREB GOD. 24 (2015), BR. 1, STR. 69-87

BUBIĆ, A.: THE ROLE OF.. ism (Concern over mistakes, Doubts about actions, Personal standards, Parental expectations, Parental criticism, and Organization), it has recently been suggested that four dimensions would be more appropriate (Stöber, 1998). These dimensions include Concern over mistakes and doubts (FMPS CMD), Parental expectations and criticism (FMPS PEC), Personal standards (FMPS PS) and Organization (FMPS O). Higher scores on these subscales, respectively, reflect higher tendencies to feel concern over one's actions, experience higher parental expectations, set high personal standards and be very organized.

\section{Emotional Regulation and Control Scale}

Emotional Regulation and Control Scale (Upitnik emocionalne regulacije i kontrole, UERK; Takšić, 2002) is a questionnaire designed for assessing the influence of negative emotions and moods on thinking, memory and behavior. It consists of 20 items (e.g., I typically notice bad things when I am in a bad mood) that describe potential influences of negative emotions and individuals' ability to regulate these influences. The participants' task is to rate the degree in which each item is characteristic of themselves using a 5-point scale $(1-$ not at all characteristic of me; 5 - very characteristic of me). Based on previous results indicating satisfactory goodness-of-fit indices and internal consistency of a one-factorial model of this scale (Takšić, 2003), participants' scores on this instrument were formed as one emotional regulation and control factor based on all scale items. For more understandable interpretation, all items were recoded in a way that higher scores on this scale indicate better emotional regulation and control. Given that this scale has thus far not been published in English, its translated version is presented in the Appendix.

\section{Short Maximizing Scale}

Short Maximizing Scale (Nenkov et al., 2008) is a scale designed for assessing individuals' decision-making style that distinguishes between two approaches, maximizing and satisficing. Maximizing represents an approach biased towards optimizing the decision-making process and striving for making the best possible decisions. In contrast, satisficing refers to a tendency to make "good enough" decisions, a process typically achieved by using heuristics and not investing too much energy into the decision-making process. This scale consists of 6 items (e.g., No matter what I do, I have the highest standards for myself) that the participants rate on a 7-point scale (1 - strongly disagree; 7 - strongly agree). Higher scores on this scale reflect higher maximization tendencies. 
DRUŠ. ISTRAŽ. ZAGREB GOD. 24 (2015), BR. 1 STR. 69-87

BUBIĆ, A.: THE ROLE OF..

(1) TABLE 1

Psychometric Pro-

perties of the Ad-

ministered Instruments

$(N=300)$

\section{Closing Alternatives Scale}

Closing Alternatives Scale is a subscale of the Decision Commitment Scale (Sparks et al., 2012), a questionnaire that assesses individuals' tendency to commit to decisions. The original scale consists of 11 items that describe situations in which one may avoid committing to a made choice by retaining the option to change one's minds that the participants rate using a 7-point scale (1 - strongly disagree; 7 - strongly agree). Since a two-factor solution of this scale has recently been proposed with one factor showing unsatisfactory psychometric properties (Bubic, 2014), in this study only the Closing Alternatives Scale that consists of 7 items (e.g., Whenever possible, I prefer to keep my options open and like when I'm not locked into a decision) was administered. Higher scores on this subscale reflect a higher tendency to commit to decisions by closing other available alternatives.

Psychometric properties of all used instruments are presented in Table 1.

\begin{tabular}{lrrrrr}
\hline Measure & $M$ & $S D$ & Min & Max & $\alpha$ \\
\hline Concern over mistakes and doubts & 28.95 & 9.91 & 13 & 60 & 0.890 \\
Parental expectations and criticism & 17.94 & 6.61 & 9 & 44 & 0.836 \\
Personal standards & 20.79 & 5.40 & 7 & 34 & 0.793 \\
Organization & 24.14 & 4.75 & 6 & 30 & 0.869 \\
Emotional regulation and control & 56.38 & 12.50 & 23 & 90 & 0.848 \\
Maximizing & 24.27 & 6.72 & 8 & 41 & 0.666 \\
Decision commitment & 29.44 & 7.18 & 7 & 49 & 0.741 \\
\hline
\end{tabular}

Note: $M$ - mean; SD - standard deviation; Min - minimum; Max - maximum; $\alpha$ - Cronbach reliability coefficient.

\section{DATA ANALYSIS}

Data analysis was conducted using Statistica 11 (StatSoft, Inc.) statistical package. Descriptive statistical analysis, a correlation and two hierarchical regression analyses were conducted in order to analyze the connections between the investigated constructs.

\section{RESULTS}

A correlation analysis was conducted as the first step in exploring the relationship between maximizing and decision commitment, emotional regulation and control as well as four dimensions of perfectionism. The obtained results indicate a significant negative correlation between two measures of decision-making styles, namely maximization and decision commitment. Furthermore, maximizing was positively correlated with three dimensions of perfectionism, namely concern over 
DRUŠ. ISTRAŽ. ZAGREB GOD. 24 (2015), BR. 1, STR. 69-87

BUBIĆ, A.: THE ROLE OF..

\section{(1) TABLE 2}

Correlation Matrix for the Tested Variables $(\mathrm{N}=300)$ mistakes and doubts, personal standards and parental expectations and criticism, while it was negatively correlated with organization as well as emotional regulation and control. A somewhat reverse pattern of correlations was obtained with respect to decision commitment that correlated negatively with concern over mistakes and doubts and personal standards, while it was positively correlated with emotional regulation and control. The remaining correlations may be found in Table 2.

\begin{tabular}{|c|c|c|c|c|c|c|}
\hline & 2 & 3 & 4 & 5 & 6 & 7 \\
\hline Concern over mistakes and doubts (1) & $0.54^{* *}$ & $0.51^{* *}$ & $-0.14^{*}$ & $-0.44^{* *}$ & $0.45^{* *}$ & $-0.32^{* *}$ \\
\hline Parental expectations and criticism (2) & & $0.29^{* *}$ & $-0.21^{* *}$ & $-0.26^{* *}$ & $0.19^{* *}$ & $-0.13^{*}$ \\
\hline Personal standards (3) & & & $0.27^{* *}$ & -0.08 & $0.20^{* *}$ & -0.09 \\
\hline Organization (4) & & & & $0.24^{* *}$ & $-0.14^{*}$ & 0.07 \\
\hline Emotional regulation and control (5) & & & & & $-0.32^{* *}$ & $0.23^{* *}$ \\
\hline Maximizing (6) & & & & & & $-0.50^{* *}$ \\
\hline Decision commitment (7) & & & . & & & \\
\hline
\end{tabular}

Note: ${ }^{*} p<0.05 ;{ }^{* *} p<0.01$.

In order to investigate the associations between maximizing, perfectionism and emotional regulation and control in more detail, a hierarchical regression analysis was performed using maximizing as a criterion (Table 3). Four dimensions of perfectionism served as predictors in the first step, while emotional regulation and control was introduced as a predictor in the second step of the analysis. In the first step only the concern over mistakes and doubts dimension of perfectionism was identified as a significant predictor of maximizing. The significant influence of this variable remained after adding emotional regulation and control that was also identified as a significant predictor in the second step of the analysis.

Next, in order to investigate the relative contributions of different factors of perfectionism, emotional regulation and control and maximizing to decision commitment, a hierarchical regression analysis was conducted using decision commitment as a criterion (Table 3). Same as in the previous analysis, four perfectionism factors were added as predictors in the first step, while emotional regulation and control was introduced as a predictor in the second step of the analysis. In addition, maximizing was added as an additional predictor in the final, third step of the analysis in order to test how the manner of approaching decision-making situations while they are being made influences the choice evaluation in the post-decision stage. With regard to the obtained results, in the first step only the concern over mistakes and doubts dimension of perfectionism was identified as a significant pre- 
(1) TABLE 3

Results of the Hierarchical Regression Analyses Using Maximizing and Decision Commitment as Criteria $(\mathrm{N}=300)$ dictor of decision commitment. The significant influence of this variable remained after adding emotional regulation and control in the second, and maximizing in the third step of the analysis. In addition, maximizing was also identified as a significant predictor of decision commitment in the final step of the analysis.

\begin{tabular}{|c|c|c|c|c|}
\hline & & & Criteria & \\
\hline & & dictors & Maximizing Dec & on commitment \\
\hline Step 1 & $\beta$ & Concern over mistakes and doubts & $0.474^{* *}$ & $-0.399 * *$ \\
\hline & & Parental expectations and criticism & -0.085 & 0.059 \\
\hline & & Personal standards & 0.010 & 0.100 \\
\hline & & Organization & -0.092 & 0.000 \\
\hline & $R$ & & 0.458 & 0.331 \\
\hline & $R^{2}$ & & 0.210 & 0.110 \\
\hline & $F$ & & $19.44^{* *}(4,293)$ & $9.04^{* *}(4,293)$ \\
\hline Step 2 & $\beta$ & Concern over mistakes and doubts & $0.406^{* *}$ & $-0.347^{* *}$ \\
\hline & & Parental expectations and criticism & -0.085 & 0.059 \\
\hline & & Personal standards & 0.028 & 0.086 \\
\hline & & Organization & -0.074 & -0.014 \\
\hline & & Emotional regulation and control & $-0.136^{*}$ & 0.105 \\
\hline & $R$ & & 0.473 & 0.344 \\
\hline & $R^{2}$ & & 0.224 & 0.118 \\
\hline & $\Delta I$ & & $0.014^{*}$ & 0.008 \\
\hline & $F$ & & $16.83^{* *}(5,292)$ & $7.82^{* *}(5,292)$ \\
\hline Step 3 & $\beta$ & Concern over mistakes and doubts & - & $-0.167^{*}$ \\
\hline & & Parental expectations and criticism & - & 0.021 \\
\hline & & Personal standards & - & 0.099 \\
\hline & & Organization & - & -0.047 \\
\hline & & Emotional regulation and control & - & 0.045 \\
\hline & & Maximizing & - & $-0.444^{* *}$ \\
\hline & $R$ & & - & 0.520 \\
\hline & $R^{2}$ & & - & 0.271 \\
\hline & $\Delta I$ & & - & $0.153^{* *}$ \\
\hline & $F$ & & - & $18.02^{* *}(6,291)$ \\
\hline
\end{tabular}

Note: ${ }^{*} p<0.05 ;{ }^{* *} p<0.01 ; \beta$ - standardized regression coefficient; $R$ - multiple correlation coefficient; $R^{2}$ - variance explained by the predictors; $\Delta R^{2}$ - change in $R^{2} ; F$ - F-ratio; $d f$ - degrees of freedom.

\section{DISCUSSION}

The current study investigated the relationship between perfectionism, emotional regulation and control and two decision-making styles, maximizing and decision commitment. As expected, the obtained findings showed a significant negative correlation between maximizing and decision commitment. Also, in line with the postulated hypotheses, maximizing was negatively associated with emotional regulation and control, while its strongest positive association was established with 
DRUŠ. ISTRAŽ. ZAGREB GOD. 24 (2015), BR. 1, STR. 69-87

BUBIĆ, A.: THE ROLE OF... respect to concern over mistakes and doubts. This dimension of perfectionism was, together with maximizing, also identified as a significant predictor of participants' decision commitment.

First, with regard to the positive correlation between perfectionism and maximizing, the obtained findings confirm and extend previous reports that have shown an association between maximizing and general self-oriented perfectionism (Schwartz et al., 2002) as well as both positive and negative aspects of perfectionism (Bergman et al., 2007). However, the present study indicates that, while focusing on specific dimensions of perfectionism, only concern over mistakes and doubts is positively related to maximizing. Interestingly, this dimension has been suggested to represent a central aspect of perfectionism (Frost et al., 1990), in particular clinical perfectionism that is highly associated with evaluative worries (Dunkley, Blankstein, Masheb, \& Grilo, 2006). Similarly, it has been argued that the negative relationship between maximizing and well-being may be explained by individuals' endless search for available information and the experienced difficulty in making decisions coupled with their belief that ideal choices may be attainable (Rim, Turner, Betz, \& Nygren, 2011). This could make maximizers more prone towards setting unrealistically optimistic expectations (Schwartz et al., 2002), resulting in subsequent disappointment and regret over own actions and choices. This pattern resembles the concern over mistakes and doubts dimension of perfectionism that is strongly associated with negative and dysfunctional aspects of perfectionism (Frost, Heimberg, Holt, Mattia, \& Neubauer, 1993; Slade \& Owens, 1998) as well as higher anxiety, depression and lower levels of self-confidence (Enns \& Cox, 1999; Frost \& Henderson, 1991; Saboonchi, Lundh, \& Öst, 1999).

Furthermore, maximizing has also been related to an increased risk of experiencing negative affect (Roets et al., 2012; Schwartz et al., 2002) that, in accordance with the present results, might be related to the individuals' inability to regulate and control own emotional experiences. Recognizing the negative association between maximizing and emotional regulation and control is relevant, as it may provide suggestions regarding the mechanisms underlying maximizing tendencies. As mentioned earlier, maximizing has been associated with positive objective decision outcomes and a negative evaluation of such outcomes (Iyengar, Wells, \& Schwartz, 2006). This can be easily explained if we consider that maximizing represents a construct that reflects our constant striving for best possible solutions, for which compromises are not acceptable. Consequently, even when they experience objec- 
DRUŠ. ISTRAŽ. ZAGREB GOD. 24 (2015), BR. 1 STR. $69-87$

BUBIĆ, A.: THE ROLE OF... tively superior results and outcomes, maximizers later compare these with potentially even better alternatives and own expectations, and are always very critical in this process (Iyengar et al., 2006; Nenkov et al., 2008; Roets et al., 2012). Given that most people, maximizers in particular, tend to set their expectations in an optimistic fashion (Schwartz et al., 2002; Weinstein, 1980), it can be expected that maximizers rarely encounter situations in which the realized outcomes outperform their expectancies and wishes. Consequently, such individuals are rarely in a situation to be fully satisfied and content with the made choices, a suggestion that resonates with findings indicating a close relationship between maximizing and regret (Schwartz et al., 2002). This pattern of cognitive-emotional coupling may be a result of a somewhat defensive approach driven by the individuals' fear of failure, low self-esteem and their inability to regulate emotional experiences. This would be similar to several aspects of neurotic perfectionism (Hamachek, 1978), which would also explain why a stronger association between maximizing and maladaptive when compared to adaptive perfectionism has previously been reported (Bergman et al., 2007). Generally, it will be important to further study the association of emotional regulation and control with maximizing, decision-making styles and general cognitive functioning in future studies, as these constructs may be highly connected and interdependent (Brackett, Mayer, \& Warner, 2004; Gross, Richards, \& John, 2006; Ledoux, 2002; Thunholm, 2004).

When interpreting the results of the present study, it is also interesting to notice that neither the parental expectations and criticism nor the personal standards dimensions of perfectionism contributed to explaining individuals' maximization scores. With respect to parental expectations and criticism, these results are not overly surprising. Specifically, while externally prescribed goals and standards have previously been associated with perfectionism (Frost et al., 1990), such an association with maximizing has not been posited (Chang et al., 2011), although some suggestions regarding the relationship between social comparison and maximizing have been reported (Schwartz et al., 2002). Despite a statistically significant positive correlation between these constructs, the lack of contribution of personal standards to maximizing as revealed by the hierarchical regression analysis was somewhat surprising. Specifically, such a contribution was expected given that maximizing has originally been suggested to incorporate a tendency to set high personal standards (Schwartz et al., 2002). However, it has later also been demonstrated that this dimension may reflect a separate construct from the 
DRUŠ. ISTRAŽ. ZAGREB GOD. 24 (2015), BR. 1, STR. 69-87

BUBIĆ, A.: THE ROLE OF... other two dimensions associated with maximizing, namely the tendency to explore various options and experience difficulty dealing with them during decision making (Nenkov et al., 2008). Among the three dimensions, psychometric explorations into the dimensionality of the maximizing tendency have also suggested that individuals' tendency to explore alternatives may be the closest to the originally proposed construct of maximizing (Rim et al., 2011). Although these suggestions may explain the lack of association between personal standards and maximizing in the present study, future studies should nevertheless explore this potential association further. It could be speculated that the results of such studies might depend on the instruments used for measuring maximizing, as these also differ with respect to the degree in which they accurately measure different facets of maximizing (Rim et al., 2011). For instance, it has been suggested that the Maximization Tendency Scale (Diab, Gillespie, \& Highhouse, 2008) is more appropriate for an accurate measurement of high standards, so using this scale might lead to a somewhat different profile of results. All of these elements suggest that, although relatively often explored, the maximizing construct is still not well understood and needs to be explored further.

Next, the results obtained in the present study indicate that perfectionism is, in addition to maximizing, also associated with the process of dealing with realized outcomes. Specifically, concern over mistakes and doubts was revealed as the only dimension of perfectionism that served as a significant predictor of decision commitment, showing that individuals who typically worry about own failures are less likely to commit to made decisions once they have been made. This finding may also be explained if we consider that prolonged dwelling over past decisions and actions often includes our consideration of alternative courses of actions that could have been taken (Roese, 1997). For people who are often concerned about own mistakes, such dysfunctional cognitions may include pondering over more negative aspects of own behavior and imagining the outcomes of potentially more successful alternative actions (Bergman et al., 2007; Weissman $\&$ Beck, 1978). Therefore, after making a certain choice, such individuals may experience difficulties forsaking the unchosen alternative options, which naturally delays their commitment to the made choice (Sparks et al., 2012). Unfortunately, such a pattern of counterfactual cognitions and delayed commitment is associated with increased feelings of regret and decreased satisfaction with the made decisions (Harmon-Jones \& Harmon-Jones, 2002; Kasimatis \& Wells, 1995). Finally, emotional regulation and control was not revealed as a sig- 
DRUŠ. ISTRAŽ. ZAGREB GOD. 24 (2015), BR. 1 STR. $69-87$

BUBIĆ, A.: THE ROLE OF... nificant predictor of decision commitment which is understandable if we consider the fact that decision commitment, as assessed in the present study, reflects primarily our cognitive response to decision outcomes (Sparks et al., 2012).

In interpreting the results from the present study, it is important to keep in mind factors that should be further explored in future research as they may limit the generalizability of the obtained findings. First, given that this was a correlational study, it is not possible to make strong claims regarding the potential causal relationships between the explored variables. In addition, a big limitation concerns the unbalanced gender distribution of students who participated in the present study. Specifically, the dominance of female students interviewed while conducting the study may be attributed to the general over-representation of female students in the majors included within this study. This needs to be taken into account when interpreting the obtained results because some previous studies have shown the existence of gender differences with regard to some decision-making styles (Byrnes, Miller, \& Schafer, 1999; Rassin \& Muris, 2005), although not systematically with regard to all styles or samples (Schwartz et al., 2002). Multicollinearity, namely high inter-correlations of predictors in regression analyses, represents another issue that should be considered when interpreting the obtained results. However, given that the multicollinearity indices calculated in the present study were satisfactory, this issue does not limit the interpretations of the obtained results.

Overall, the findings obtained in the present study provide important insights into the interrelations between perfectionism and decision making, as well as individuals' emotional functioning. Once again, they show that characteristics that are often investigated separately, in the context of e.g., decision making and personality or clinical psychology in case of maximizing and perfectionism, may share some underlying mechanisms and outcomes. As shown in the present and previous studies (Chang et al., 2011; Schwartz et al., 2002), this does not imply that they should be considered as redundant constructs. Instead, their interrelations should be explored and conceptualized in more detail, as this may result in deeper understanding of our cognitive and emotional functioning, as well as behaviors and life outcomes. Also, this exploration may aid us in understanding the close interplay between these domains that are often examined separately. Additional arguments for associating them more closely come from rare studies indicating that, instead of considering decision-making styles as pure cognitive habits and practices, these should be viewed as constructs that also involve basic self-evaluation and self-regulation abilities (Thunholm, 2004). 
The present study explored the relationship between four dimensions of perfectionism, emotional regulation and control, maximizing and decision commitment. The obtained results indicate that maximizing is primarily related to concern over mistakes and doubts that may be regarded as one of the central aspects of perfectionism. Furthermore, maximizing is related to emotional regulation and control, a finding that may explain why maximizers are more likely to experience negative affect and often regret the outcomes of their decisions. In addition, the obtained results indicate maximizing and concern over mistakes and doubts as significant predictors of decision commitment. These findings confirm and extend previous reports indicating a close relationship between maximizing and perfectionism, providing novel insights into their association with emotional regulation and control.

\section{APPENDIX}

The Emotional Regulation and Control Scale (Takšić, 2002)

1. I recall situations in which I was angry very well.

2. I react quickly and very strongly when somebody makes me angry.

3. I usually cannot say anything clever when I get scared of something or somebody.

4. I feel hopeless when something bad happens to me.

5. I typically notice bad things when I am in a bad mood.

6. It is hard for me to solve even the simplest tasks when I am in a bad mood.

7. When I get very angry, I feel like I am losing control.

8. When I get very engaged in a discussion, I sometimes feel as if I am right about everything.

9. I fail to notice things around me when I get angry.

10. When I am in a bad mood, even the smallest problems seem unsolvable.

11. I postpone doing small house chores for later when I am in a bad mood.

12. Sometimes my feelings get out of control.

13. I remember events that evoked negative emotions in me the best.

14. It is hard for me to forgive people who had made me angry or sad.

15. I am cautious when approaching a person who had hurt me before.

16. I don't start working seriously until I am left with little time to finish the task.

17. I can remember moments in which I was sad particularly well.

18. Mood strongly influences my thinking.

19. It is hard for me to forget things that had upset me.

20. When I am angry, I blow up at people who had done nothing wrong to me.

Note: All items are reverse-coded so that a higher score on this scale indicates better emotional regulation and control. 
Aldea, M. A., \& Rice, K. G. (2006). The role of emotional dysregulation in perfectionism and psychological distress. Journal of Counseling Psychology, 53(4), 498-510. doi:10.1037/0022-0167.53.4.498

Appelt, K. C., Milch, K. F., Handgraaf, M. J., \& Weber, E. U. (2011). The Decision Making Individual Differences Inventory and guidelines for the study of individual differences in judgment and decision-making research. Judgment and Decision Making, 6(3), 252-262.

Ariely, D., \& Norton, M. I. (2011). From thinking too little to thinking too much: A continuum of decision making. Wiley Interdisciplinary Reviews: Cognitive Science, 2(1), 39-46. doi:10.1002/wcs.90

Bergman, A. J., Nyland, J. E., \& Burns, L. R. (2007). Correlates with perfectionism and the utility of a dual process model. Personality and Individual Differences, 43(2), 389-399. doi:10.1016/j.paid. 2006.12.007

Brackett, M. A., Mayer, J. D., \& Warner, R. M. (2004). Emotional intelligence and its relation to everyday behaviour. Personality and Individual Differences, 36(6), 1387-1402. doi:10.1016/S01918869(03)002368

Bubic, A. (2014). Decision making characteristics and decision styles predict adolescents' career choice satisfaction. Current Psychology, 33(4), 515-531. doi:10.1007/s12144-014-9226-5

Burns, D. D. (1980). The perfectionist's script for self-defeat. Psychology Today, 14(6), 34-52.

Byrnes, J. P., Miller, D. C., \& Schafer, W. D. (1999). Gender differences in risk taking: A meta-analysis. Psychological Bulletin, 125(3), 367-383. doi:10.1037/0033-2909.125.3.367

Chang, E. C., Lin, N. J., Herringshaw, A. J., Sanna, L. J., Fabian, C. G., Perera, M. J., \& Marchenko, V. V. (2011). Understanding the link between perfectionism and adjustment in college students: Examining the role of maximizing. Personality and Individual Differences, 50(7), 1074-1078. doi:10.1016/j.paid.2011.01.027

Diab, D. L., Gillespie, M. A., \& Highhouse, S. (2008). Are maximizers really unhappy? The measurement of maximizing tendency. Judgment and Decision Making Journal, 3(5), 364-370.

Dunkley, D. M., Blankstein, K. R., Masheb, R. M., \& Grilo, C. M. (2006). Personal standards and evaluative concerns dimensions of "clinical" perfectionism: A reply to Shafran et al. $(2002,2003)$ and Hewitt et al. (2003). Behaviour Research and Therapy, 44(1), 63-84. doi:10.1016/j.brat.2004.12.004

Ellis, A. (1962). Reason and emotion in psychotherapy. New York: Birch Lane Press.

Enns, M. W., \& Cox, B. J. (1999). Perfectionism and depression symptom severity in major depressive disorder. Behaviour Research and Therapy, 37(8), 783-794. doi:10.1016/S0005-7967(98)00188-0

Enns, M. W., \& Cox, B. J. (2002). The nature and assessment of perfectionism: A critical analysis. In G. L. Flett, \& P. L. Hewitt (Eds.), Perfectionism: Theory, research, and treatment (pp. 33-62). Washington D.C.: American Psychological Association. doi:10.1037/10458-002 
DRUŠ. ISTRAŽ. ZAGREB GOD. 24 (2015), BR. 1, STR. 69-87

BUBIĆ, A.: THE ROLE OF..
Frost, R. O., Heimberg, R. G., Holt, C. S., Mattia, J. I., \& Neubauer, A. L. (1993). A comparison of two measures of perfectionism. Personality and Individual Differences, 14(1), 119-126. doi:10.1016/0191-8869(93)901812

Frost, R. O., \& Henderson, K. J. (1991). Perfectionism and reactions to athletic competition. Journal of Sport E Exercise Psychology, (13), 323-335.

Frost, R. O., Marten, P., Lahart, C., \& Rosenblate, R. (1990). The dimensions of perfectionism. Cognitive Therapy and Research, 14(5), 449-468. doi:10.1007/BF01172967

Garner, D. M., Olmstead, M. P., \& Polivy, J. (1983). Development and validation of a multidimensional eating disorder inventory for anorexia nervosa and bulimia. International Journal of Eating Disorders, 2(2), 15-34. doi:10.1002/1098-108X(198321)2:2<15::AID-EAT22600202 $03>3.0 . \mathrm{CO} ; 2-6$

Greblo, Z. (2012). Što se skriva iza pojma "perfekcionizam"? Povijest proučavanja i pregled različitih konceptualizacija perfekcionizma [What is hidden behind the term "perfectionism"? Historical overview of different approaches to the study of perfectionism]. Psihologijske teme, 21(1), 195-212.

Gross, J. J., Richards, J. M., \& John, O. P. (2006). Emotion regulation in everyday life. In D. Snyder, J. Simpson, \& J. N. Hughes (Eds.), Emotion regulation in couples and families: Pathways to dysfunction and health (Vol. 2006, pp. 13-35). Washington, DC: American Psychological Association. doi:10.1037/11468-001

Hamachek, D. E. (1978). Psychodynamics of normal and neurotic perfectionism. Psychology: A Journal of Human Behavior, 15(1), 27-33.

Harmon-Jones, E., \& Harmon-Jones, C. (2002). Testing the action-based model of cognitive dissonance: The effect of action orientation on postdecisional attitudes. Personality and Social Psychology Bulletin, 28(6), 711-723. doi:10.1177/0146167202289001

Hewitt, P. L., \& Flett, G. L. (1991). Perfectionism in the self and social contexts: Conceptualization, assessment, and association with psychopathology. Journal of Personality and Social Psychology, 60(3), 456-470. doi:10.1037/0022-3514.60.3.456

Hill, R. W., McIntire, K., \& Bacharach, V. R. (1997). Perfectionism and the Big Five factors. Journal of Social Behavior E Personality, 12(1), 257-270. Iyengar, S. S., Wells, R. E., \& Schwartz, B. (2006). Doing better but feeling worse: Looking for the "best" job undermines satisfaction. Psychological Science, 17(2), 143-150. doi:10.1111/j.1467-9280.2006.01677.x

Kahneman, D., \& Tversky, A. (1979). Prospect theory: An analysis of decision under risk. Econometrica: Journal of the Econometric Society, 47(2), 263-291. doi:10.2307/1914185

Kahneman, D., \& Tversky, A. (1984). Choices, values, and frames. American Psychologist, 39(4), 341-350. doi:10.1037/0003-066X.39.4.341

Kasimatis, M., \& Wells, G. L. (1995). Individual differences in counterfactual thinking. In N. J. Roese, \& J. M. Olson (Eds.), What might 
DRUŠ. ISTRAŽ. ZAGREB GOD. 24 (2015), BR. 1 STR. $69-87$

BUBIĆ, A.: THE ROLE OF... have been: The social psychology of counterfactual thinking (pp. 81-101). Hillsdale, NJ: Lawrence Erlbaum Associates, Inc.

Ledoux, J. (2002). Cognitive-emotional interactions: Listen to the brain. In R. D. Lane, \& L. Nadel (Eds.), Cognitive neuroscience of emotion (pp. 129-155). Oxford University Press.

Lo, A., \& Abbott, M. J. (2013). Review of the theoretical, empirical, and clinical status of adaptive and maladaptive perfectionism. Behaviour Change, 30(02), 96-116. doi:10.1017/bec.2013.9

Nenkov, G., Morrin, M., Schwartz, B., Ward, A., \& Hulland, J. (2008). A short form of the Maximization Scale: Factor structure, reliability and validity studies. Judgment and Decision Making, 3(5), 371-388.

Rassin, E., \& Muris, P. (2005). To be or not to be... indecisive: Gender differences, correlations with obsessive-compulsive complaints, and behavioural manifestation. Personality and Individual Differences, 38(5), 1175-1181. doi:10.1016/j.paid.2004.07.014

Rim, H. B., Turner, B. M., Betz, N. E., \& Nygren, T. E. (2011). Studies of the dimensionality, correlates, and meaning of measures of the maximizing tendency. Judgment and Decision Making, 6(6), 565-579.

Roese, N. J. (1997). Counterfactual thinking. Psychological Bulletin, 121(1), 133-148. doi:10.1037/0033-2909.121.1.133

Roets, A., Schwartz, B., \& Guan, Y. (2012). The tyranny of choice: A cross-cultural investigation of maximizing-satisficing effects on well-being. Judgment and Decision Making, 7(6), 689-704.

Rudolph, S. G., Flett, G. L., \& Hewitt, P. L. (2007). Perfectionism and deficits in cognitive emotion regulation. Journal of Rational-Emotive $\mathcal{E}$ Cognitive-Behavior Therapy, 25(4), 343-357. doi:10.1007/s10942-007-0056-3

Saboonchi, F., Lundh, L.-G., \& Öst, L.-G. (1999). Perfectionism and self-consciousness in social phobia and panic disorder with agoraphobia. Behaviour Research and Therapy, 37(9), 799-808. doi:10.1016/S00057967(98)00183-1

Schneider, W., \& Shiffrin, R. M. (1977). Controlled and automatic human information processing: I. Detection, search, and attention. Psychological Review, 84(1), 1-66. doi:10.1037/0033-295X.84.1.1

Schwartz, B. (2000). Self-determination: The tyranny of freedom. American Psychologist, 55(1), 79-88. doi:10.1037/0003-066X.55.1.79

Schwartz, B., Ward, A., Monterosso, J., Lyubomirsky, S., White, K., \& Lehman, D. R. (2002). Maximizing versus satisficing: Happiness is a matter of choice. Journal of Personality and Social Psychology, 83(5), 1178-1197. doi:10.1037/0022-3514.83.5.1178

Shafran, R., Cooper, Z., \& Fairburn, C. G. (2002). Clinical perfectionism: A cognitive-behavioural analysis. Behaviour Research and Therapy, 40(7), 773-791. doi:10.1016/S0005-7967(01)00059-6

Shiffrin, R. M., \& Schneider, W. (1977). Controlled and automatic human information processing: II. Perceptual learning, automatic attending and a general theory. Psychological Review, 84(2), 127-190. doi:10.1037/0033-295X.84.2.127 
DRUŠ. ISTRAŽ. ZAGREB GOD. 24 (2015), BR. 1, STR. 69-87

BUBIĆ, A.: THE ROLE OF...
Shiffrin, R. M., \& Schneider, W. (1984). Automatic and controlled processing revisited. Psychological Review, 91(2), 269-276. doi:10.1037/0033295X.91.2.269

Simon, H. A. (1955). A behavioral model of rational choice. The Quarterly Journal of Economics, 69(1), 99-118. doi:10.2307/1884852

Slade, P. D., \& Owens, R. G. (1998). A dual process model of perfectionism based on reinforcement theory. Behavior Modification, 22(3), 372-390. doi:10.1177/01454455980223010

Sparks, E. A., Ehrlinger, J., \& Eibach, R. P. (2012). Failing to commit: Maximizers avoid commitment in a way that contributes to reduced satisfaction. Personality and Individual Differences, 52(1), 72-77. doi:10.1016/j.paid.2011.09.002

Stöber, J. (1998). The Frost Multidimensional Perfectionism Scale revisited: More perfect with four (instead of six) dimensions. Personality and Individual Differences, 24(4), 481-491. doi:10.1016/S01918869(97)00207-9

Stöber, J., \& Otto, K. (2006). Positive conceptions of perfectionism: Approaches, evidence, challenges. Personality and Social Psychology Review, 10(4), 295-319. doi:10.1207/s15327957pspr1004_2

Takšić, V. (2002). Upitnici emocionalne inteligencije (kompetentnosti) UEK [The questionnaires of emotional intelligence and competence]. In T. Lacković-Grgin, A. Proroković, V. Ćubela, \& Z. Penezić (Eds.), Zbirka psihologijskih skala i upitnika, Svezak 1 [Collection of psychological scales and questionnaires, Vol. 1] (pp. 27-42). Zadar, Croatia: Sveučilište u Zadru [University of Zadar].

Takšić, V. (2003). Skala emocionalne regulacije i kontrole (ERIK): provjera faktorske strukture [Emotional regulation and control scale: Evaluation of the factor structure]. Psihologijske teme, 12(1), 43-54.

Thunholm, P. (2004). Decision-making style: Habit, style or both? Personality and Individual Differences, 36(4), 931-944. doi:10.1016/S01918869(03)00162-4

Von Neumann, J., \& Morgenstern, O. (1944). Theory of games and economic behavior. Princeton, NJ: Princeton University Press.

Weinstein, N. D. (1980). Unrealistic optimism about future life events. Journal of Personality and Social Psychology, 39(5), 806-820. doi:10.1037/ 0022-3514.39.5.806

Weissman, A. N., \& Beck, A. T. (1978). Development and validation of the Dysfunctional Attitude Scale: A preliminary investigation. Presented at the American Education Research Association, Toronto, Canada.

Zubčić, T., \& Vulić-Prtorić, A. (2008). Multidimenzionalna skala perfekcionizma MPS-F [Frost Multidimensional Perfectionism Scale]. In Z. Penezić, V. Ćubela Adorić, A. Proroković, \& I. Tucak Junaković (Eds.), Zbirka psihologijskih skala i upitnika 4 [Collection of Psychological Scales and Questionnaires, Vol. 4$]$ (pp. 23-35). Zadar, Croatia: Sveučilište $\mathrm{u}$ Zadru [University of Zadar]. 
DRUŠ. ISTRAŽ. ZAGREB GOD. 24 (2015), BR. 1 STR. $69-87$

BUBIĆ, A.: THE ROLE OF..

\section{Uloga perfekcionizma i emocionalne regulacije u objašnjenju stilova odlučivanja}

\section{Andreja BUBIĆ}

Filozofski fakultet, Split

Ljudi se međusobno znatno razlikuju s obzirom na stilove odlučivanja, odnosno načine na koje vobičajeno pristupaju procesu donošenja odluka. Dok neki u pravilu odluke donose brzo i bez oklijevanja, drugi provode znatno više vremena u odlučivanju čak i o malim, svakodnevnim stvarima te svaku odluku preispituju dugo nakon donošenja. Cilj ovog istraživanja bio je detalinije ispitati odnos između stilova donošenja odluka, perfekcionizma te emocionalne regulacije i kontrole. $U$ istraživanju je sudjelovalo 300 studenata društvenih i humanističkih usmjerenja, koji su ispunili instrumente za mjerenje sklonosti maksimiziranju, posvećenosti odlukama, perfekcionizma te emocionalne regulacije i kontrole. Dobiveni rezultati pokazali su da je sklonost maksimiziranju prije svega povezana s jednom dimenzijom perfekcionizma, brigom o vlastitim pogreškama i sumnjama, kao i emocionalnom regulacijom. Nadalje, maksimiziranje i briga o vlastitim pogreškama i sumnjama izdvojeni su kao značajni prediktori posvećenosti odlukama. Ovi rezultati dopunjuju prijašnje nalaze koji se odnose na povezanost maksimiziranja i perfekcionizma te nude relevantne uvide $u$ njihovu povezanost s emocionalnom regulacijom. Rezultati pokazuju i važnost daljnjeg istraživanja ovih konstrukata, koji se, unatoč svojoi složenoj međuovisnosti, najčešće ispituju u odvojenim kontekstima i područjima.

Ključne riječi: posvećenost odlukama, odlučivanje, emocionalna regulacija, maksimiziranje, perfekcionizam 